\title{
Zelkova carpinifolia reservoir from Hyrcanian Forests, Northern Iran, a new sacrifice of Ophiostoma novo-ulmi
}

\author{
AKRAM AHMADI ${ }^{1, \boldsymbol{\varphi}}$, MOHAMMAD REZA KAVOSI ${ }^{1}$, HASSAN SOLTANLOO ${ }^{2}$ \\ ${ }^{1}$ Department of Forest Ecology, Faculty of Forest Sciences, Gorgan University of Agricultural Sciences and Natural Resources, Gorgan, \\ Golestan, Iran. Tel. /Fax. +98 171 2227867, ’email: ahmadi.1870@gmail.com \\ ${ }^{2}$ Department of Plant Breeding and Biotechnology, Gorgan University of Agricultural Sciences and Natural Resources, Gorgan, Golestan, Iran.
}

Manuscript received: 30 September 2013. Revision accepted: 31 October 2013.

\begin{abstract}
Ahmadi A, Kavosi MR, Soltanloo H. 2014. Zelkova carpinifolia reservoir from Hyrcanian Forests, Northern Iran, a new sacrifice of Ophiostoma novo-ulmi. Biodiversitas 15: 48-52. Zelkova carpinifolia belongs to the Ulmaceae. It is the only species from Zelkova genus that has been distributed and is native to Iranian forests. This tree species is one of the valuable species that is comprised of endangered plants. Nevertheless, the most of reservoirs of this species have been faced to problems that fungal disease is one of the important and lethal disturbance. This study was conducted to identify the main disturbance which has been resulted in Z. carpinifolia decadence in Daland forest reservoir, North of Iran. The study has ensured that O. novo-ulmi is the fungal pathogen in this forest reservoir. It can be reminded that this pathogen had been previously found in Ulmus genus which has been created devastating event in these noteworthy reservoirs. Some symptoms which were observed in field comprising flagging and wilting of leaves. Bark beetle galleries and occlusion of xylem vessels were the other evidence of fungal disease. In light of laboratory results, the fungi colony was fluffy, light-colored and fast-growing. The different shapes of fungi growth like white fibrous and flower shape or dark petaloid shape were observed. Mean colony diameters of $O$. novo-ulmi were $3.72 \pm 0.16 \mathrm{~mm} /$ day in the dark at $20{ }^{\circ} \mathrm{C}$. Simultaneously, Microscopic analysis of sexual and asexual systems of $O$. novo-ulmi using a light microscope, a stereo microscope, and a scanning electron microscope revealed that it had morphological features of sporothix, pesotum, yeast-like and perithecium synanon morphology.
\end{abstract}

Key words: Hyrcanian forest, Ophiostoma novo-ulmi, pathogen, symptom, Zelkova carpinifolia

\section{INTRODUCTION}

Zelkova carpinifolia (Pall.) K. Koch, 1849 species from Elm family (Ulmaceae) has been dispersed in East Anatolia, Caucasus, North and West of Iran. Ten species of Zelkova exist worldwide (Chen and Huang, 1999; Jin et al. 2009) but only one of them is native to Iranian forests. It has distribution in Golestan, Guilan, Mazandaran, Azerbaijan, Kurdistan, Khorasan and Tehran provinces of Iran. Zelkova carpinifolia with high quality wood and a beautiful canopy in northern forests are valuable. There are few reservoirs of $Z$. carpinifolia. The destruction of lowland forests and overly harvesting of Zelkova trees, also new disease, Dutch elm disease has caused rapid extinction of this endangered species in the $Z$. carpinifolia reservoir, in Daland Park, Golestan province, North of Iran.

Ophiostoma novo-ulmi is subspecies of O. ulmi that caused second pandemic of Dutch elm disease (DED) and was more aggressive (Brasier 1996; Brasier et al. 2000; Paoletti 2006). O. novo-ulmi is separated into two distinct subspecies, novo-ulmi and americana (Brasier and Kirk 2001; Solla et al. 2008). This fungus creates a vascular wilt disease (Sinclair and Campana 1978; Stipes and Campana 1981; Brasier 1991; Dunn 2000; Jacobi et al. 2007). The pathogens are commonly spread from tree by root grafts and bark beetles (Parker et al. 1941; Stipes and Campana 1981; Webber and Gibbs 1989; Jacobi et al. 2007). This fungus belongs to Ophiostomaceae, Ophiostomatales, Ascomycota (Cannon and Kirk 2007). It is necessary to cited, this fungus is declining Zelkova reservoirs by $O$. novo-ulmi with tangible rate which has been already observed on elm trees but today it has infected Zelkova trees, another genus of Ulmaceae.

The first comprehensive study about disease on Zelkova trees has been reported by Rahnama (2004) that was due to invasive and new strain of $O$. novo-ulmi. This strain is derived from $O$. ulmi that is divided to two subspecies of $O$. novo-ulmi ssp. novo-ulmi and O. novo-ulmi ssp. americana. Unfortunately, this aggressive fungus is infecting other trees. Solla et al. (2005) reported this virulent fungal pathogen caused leaf wilting and subsequent mortality to all three elm species (Ulmus spp.) native to Europe and they had the first report in Iberian Peninsula.

The objectives of this study were isolation and identification of pathogen which has infected $Z$. carpinifolia trees in North of Iran, which faced these Zelkova trees to extinction event with high rate. 

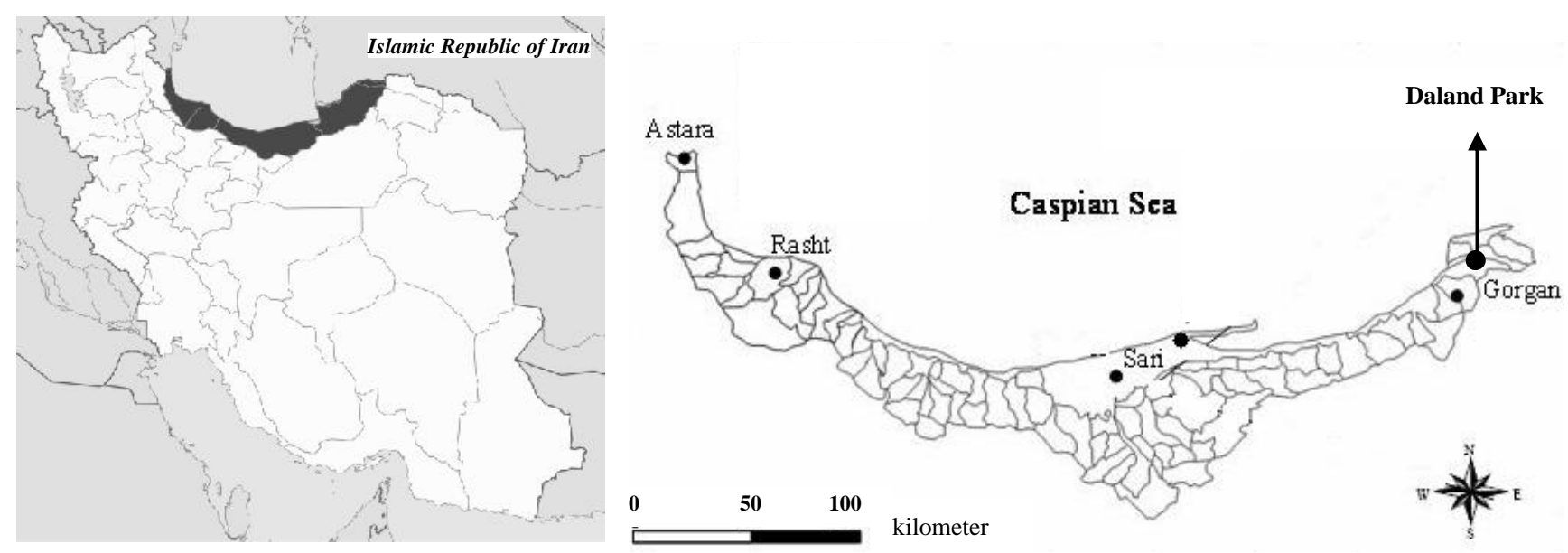

Figure 1. Location of the study site inside Daland park, the part of Hyrcanian forests, Golestan, North of Iran

\section{MATERIALS AND METHODS}

Daland forest reservoir is one of rare reservoir of Zelkova carpinifolia which has been located in Golestan province, North of Iran (Figure 1). This reservoir has been encountered with rapid extinction due to fungi infection. Sampling was performed from trees that had symptoms of disease. Disks from stem segments of Z carpinifolia trees were removed which showing characteristic dark spots in cross section. Each tree had symptoms of DED but had evidence of infestation by bark beetles. Stems with necrotic symptoms were transferred to laboratory. Stems were cut into $0.5 \mathrm{~cm}$ thickness and after surface sterilizing cultured on WA $2 \%$ and were incubated at $20^{\circ} \mathrm{C}$ for up to three weeks in an incubation chamber.

After growth of fungi, it cultured on potato dextrose agar and malt extract agar media. The strains were isolated. Liquid medium of potato dextrose used for preparing suspension of fungi spore. Some fungi characteristic such as the growth rate, appearance characteristic of fungi, colony and spore were studied and compared with mycology resources (Hunt 1965; De Hoog 1974; Barnett and Hunter 1998; Eriksson et al. 2003).

\section{RESULTS AND DISCUSSION}

The preliminary results indicated that limbs, leaves and sometimes entire of $Z$. carpinifolia trees shown symptoms of dieback. This is one of important symptoms which called flagging. It was really sensible in most of trees. In flagging a branch or branches of tree had clearly symptoms of wilting or yellowing of leaves while other branches were healthy (Figure 2). Removing a patch of bark was evident that there was bark beetle which had been created galleries underneath (Figure 3). Bark beetle galleries are one of important symptoms of Dutch elm disease. In cross section of stems, circles of brown dots, browning and infected sapwood was obvious that occurred death of xylem cells because of disturbance in water conducting (Figure 4.A). In Figure (4.B), occlusion of xylem vessels is observable that are due to tyloses.
Several fungal isolates were obtained from the stem segments of $Z$. carpinifolia. They grew well in the PDA media. They showed the same morphology and growth pattern. Mycological properties of the fungi including colony shape and color growth were described.

The colony color of isolations incubated at $20^{\circ} \mathrm{C}$ was first white, gradually creamy to creamy grayish with flower shape in the center of Petri-dish on PDA. 7th days old culture on potato dextrose agar has been shown in figure 5 . Colony color on MEA represented that these fungi had colonies with white mycelium when young, turning dark brown as they became older. Colony shape of O. novo-ulmi on PDA was white fibrous and in some older colonies, dark petaloid shape were formed at the center of Petri dishes. Mean colony diameters ( \pm standard deviation) for $O$. novoulmi, were $3.72( \pm 0.16) \mathrm{mm} /$ day in the dark at $20{ }^{\circ} \mathrm{C}$.

These results implied that there were sexual and asexual reproduction systems of Sporothrix, the phase of spore production, is shown in figure 6 . The Conidia were small and oval shape which formed in clusters on short mycelium branches and have size of 2-3×4-6 $\mu \mathrm{m}$ (Figure 7). The conidia produce mycelium via budding and germinating to produce mycelium. These conidia represented asexual reproduction system.

The isolate formed synnemata and droplets of conidia at the apex of the synnemata which denoted in Pesotum phase. In this phase, conidia masses on synnemata were almost yellow and oval shape with size of $1-3 \times 2-5 \mu \mathrm{m}$. The conidia were located on the apex of synnemata with 1-2 $\mathrm{mm}$ height. The scanning electron micrograph (SEM) of Conidia, synnemata and mycelium are shown in figure 8 . In PDA rotating liquid media appeared yeast-like phase which individual cells germinated and the spores had different size. Yeast-like phase can be seen in figure 8.

Perithecium represents sexual system of fungi. In this step, Ascosporic were produced in a black fruiting body called Perithecium (Figure 9). Ascosporic were spherical with long neck Perithecium. Ascosporous were produced in asci which degenerate inside of black fruiting body (Perithecium). The measurements revealed that the neck length was $460( \pm 175)$ micrometers and width of basis was $100( \pm 35)$. 


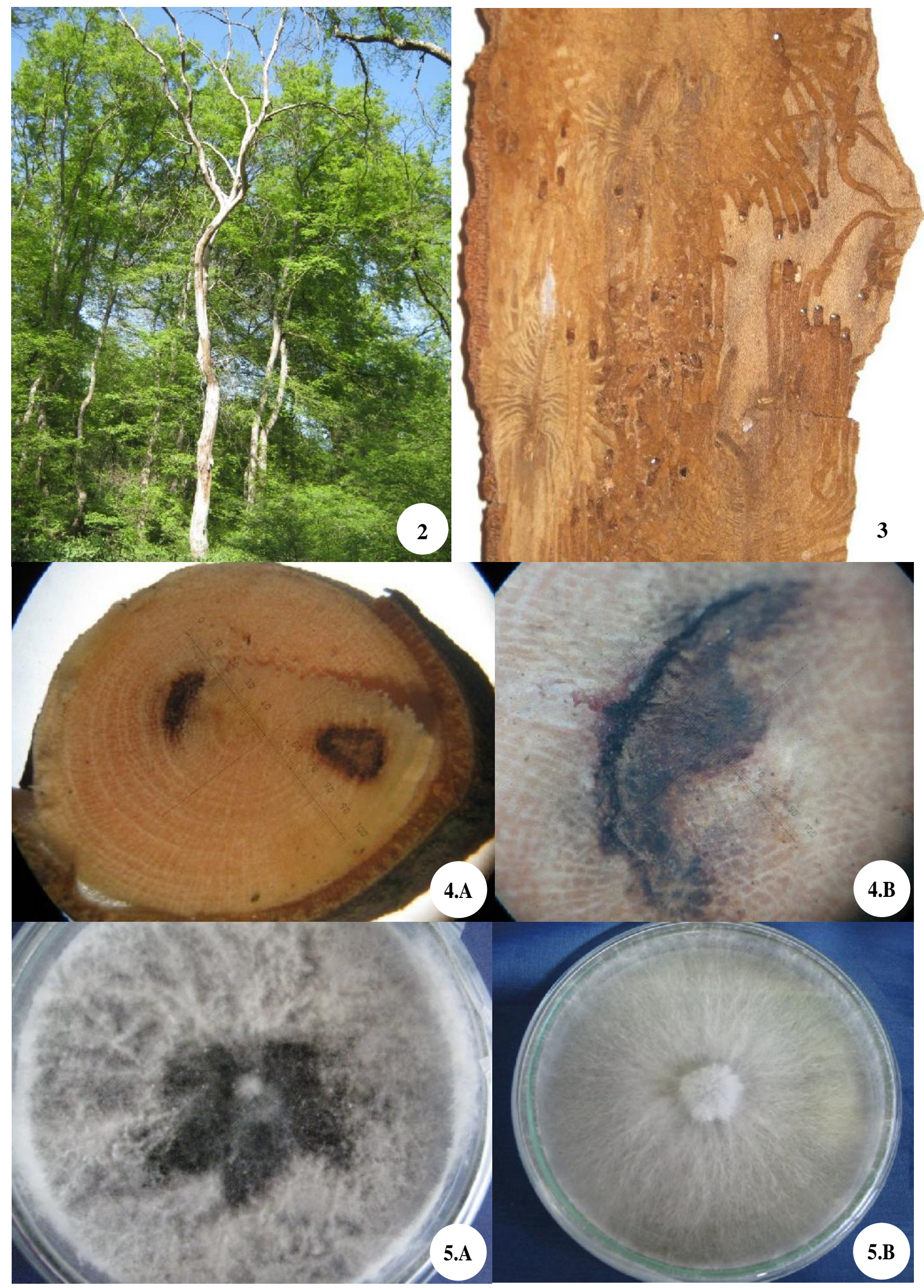




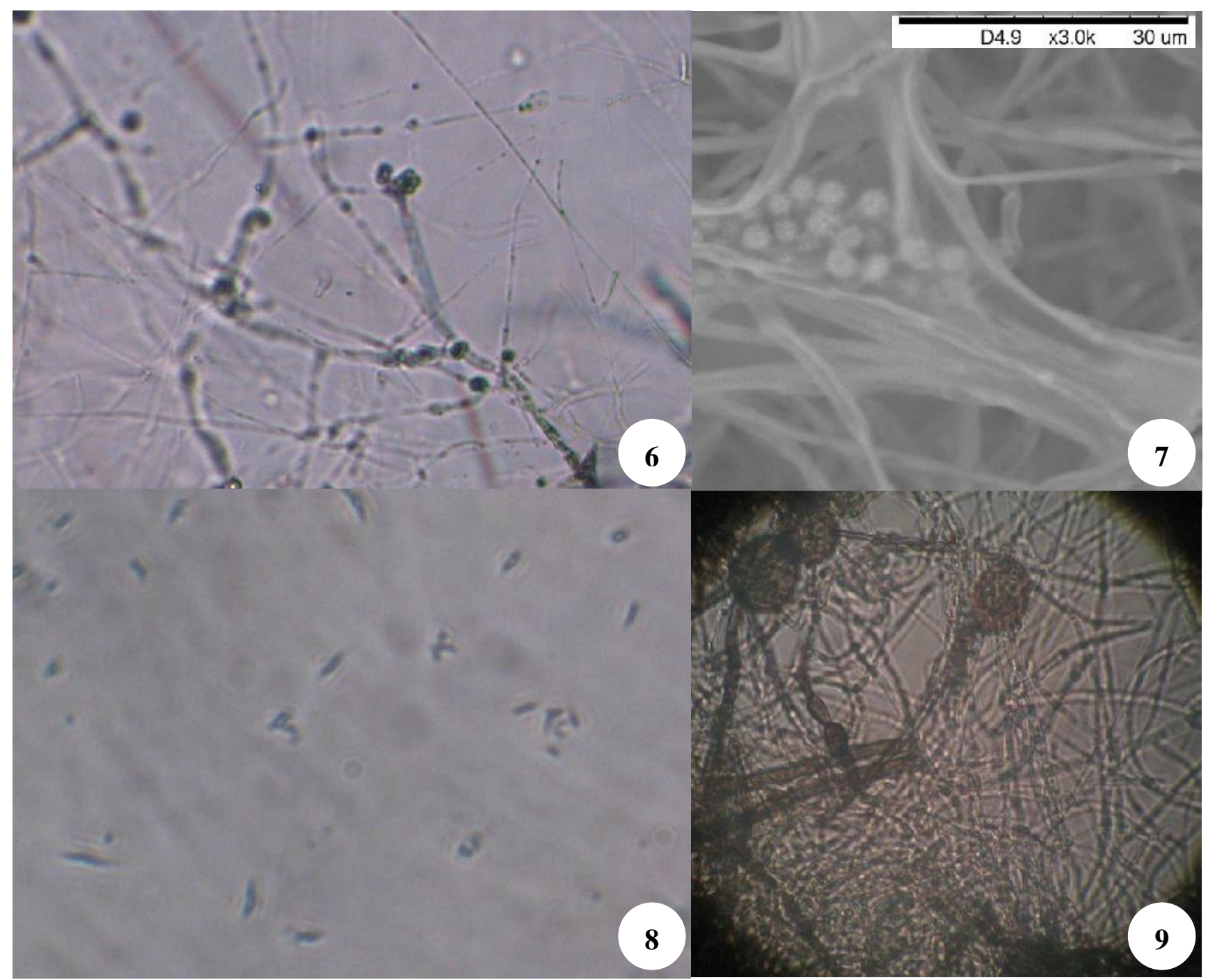

Figure 2. Symptoms of dieback in Z. carpinifolia trees

Figure 3. Bark beetle galleries underneath the bark of $Z$. carpinifolia

Figure 4. A and B, Cross section of an O. novo-ulmi infected Z. carpinifolia branch, showing characteristic dark spots in the wood

Figure 5. A and B, Colony morphology of $O$. novo-ulmi grown at $25^{\circ} \mathrm{C}$ on PDA (potato dextrose agar) medium

Figure 6. The Sporothrix phase with the small and oval shape conidia in clusters on short mycelium branches

Figure 7. The scanning electron micrograph (SEM) of conidia, synnemata and mycelium (Pesotum phase)

Figure 8. Yeast-like phase with individual cells

Figure 9. The black fruiting bodies (Perithecium) which ascospores were produced in inside them

\section{Discussion}

One of terrible declining in Zelkova carpinifolia trees is happening. The disease has been a devasting event in the reservoir of $Z$. carpinifolia. Most of researches are working on $u l m$ trees and their disease. Despite of informing to all related organization such as natural rescorces and environment organization, they were not serious to solve this problem. This project was a preliminary attempt in determining the cause of $Z$. carpinifolia trees decline. Our forest arouse proved that has been happened and continues epidemic dieback with high rate in most of $Z$. carpinifolia trees in Daland reservoir.

The first symptom which observed was flagging and wilting or yellowing of leaves. Browning at the stem segments was another witness of Ophiostoma genus, as well. Bark beetle was another field symptom that we suspected the Ophiostoma fungi is infecting this reservoir of $Z$. carpinifolia which is rare species in Iran and is extinct with high rate. More studies were performed in laboratory for distinguishing the species of Ophiostoma genus. Morphological characters comprising growth rate, appearance characteristic of fungi, colony and spore. This fungi was studied and were compared with mycology resources that revealed the fungi pathogen was morphologically similar to O. novo-ulmi (Hunt 1965; De Hoog 1974; Barnett and Hunter 1998; Eriksson et al. 2003).

The mycelium of $O$. novo-ulmi on PDA was abundant and fluffy. These fungi produced light-colored, fastgrowing colonies. The growth rate of fungi revealed that that this testimony was related to presence of O. novo-ulmi. 
The different shapes of fungi growth like white fibrous and dark petaloid shape, were other sign of O. novo-ulmi. All the colonies were morphologically typical for $O$. novoulmi. Analogous investigations were carried out by Masuya et al. (2009), they reported that the mean growth rates of $O$. novo-ulmi isolates at $20^{\circ} \mathrm{C}$ were $3.74( \pm 0.17) \mathrm{mm} /$ day. The results showed that four types of spore were observed through this research that comprised of sporothix, pesotum, yeast-like and perithecium. The sporothix is an asexual state of this species that can produce abundantly in cultures and could be identified easily under the light microscope. This research demonstrated that in sporothix phase, the observed Conidia were small and were formed at the end of mycelium branches which extend mycelium net trough budding and germinating which agrees with results of D'Arcy (2000).

The scanning electron micrograph (SEM) of Conidia and synnemata proved the Pesotum phase in experiment. In Pesotum anamorph, synnemata and droplets of conidia at the top of the synnemata were observed that formed oval shape conidia $(1-3 \times 2-5 \mu \mathrm{m})$ on the apex of synnemata $(1-2$ $\mathrm{mm})$. It is necessary to note that, these spores may shift from infected trees to healthy trees. It was an interesting fact, that in PDA rotating liquid medium, Yeast-like phase were observed. Stipes and Campana (1981) reported that this reproduction phase of fungi may interfere in pathogen propagation at xylems. Ascospores and asci in Perithecium, proved the presence of sexual reproduction system in this fungus. Two sexual and asexual reproduction systems were observed in this study.

The occurrence of $O$. novo-ulmi on wounds of $Z$. carpinifolia in this study has expanded the host range of the fungus in Iran. Zelkova carpinifolia has not a cosmopolitan distribution and is native to Iran. Its occurrence in Zelkova trees, a native tree species, expands further the wide host range of this fungus. The fungus has previously been reported from many researches. At the base of our investigations we drew a conclusion; $O$. novo ulmi has been distributed on Z. carpinifolia. Maybe it can be associated with other pathogens which extra studies special in this reservoir is necessary. Future studies seems necessary in genetic filed for proving extra information special for determining the subspecies of $O$. novo-ulmi which can be distinguished by genetic Markers (Hoegger et al. 1996).

\section{CONCLUSION}

This is the first report of $O$. novo-ulmi presence in Daland reservoir of $Z$. carpinifolia. Today, researchers have been reported the evidence of hybridization among the subspecies in some countries such as Ireland, Germany and Italy. This power in making new hybrids leads to create new strains unperidictable and maybe more aggressive (Brasier et al. 2004; Solla et al. 2005). It is necessary to note, that the differentiation of the new hybrids is not easy based only on morphological characters. Therefore, more molecular research is needed for identification of the subspecies and maybe new hybrids of this species.

\section{REFERENCES}

Barnett H, Hunter B. 1998. Illustrated Genera of Imperfect. $4^{\text {th }}$ ed. APS Press, St. Paul.

Brasier CM, Buck K, Paoletti L, Crawford L, Kirk SA. 2004. Molecular analysis of evolutionary changes in populations of Ophiostoma novoulmi. Investigación Agraria Sistemasy Recursos Forestales 13: 93-103.

Brasier CM, Kirk SA. 2000. Survival of clones of NAN Ophiostoma novo-ulmi around its probable center of appearance in North America. Mycol Res 104: 1322-1332.

Brasier CM, Kirk SA. 2001. Designation of the EAN and NAN races of Ophiostoma novo-ulmi as subspecies. Mycol Res 105: 547-554.

Brasier CM. 1991. Ophiostoma novo-ulmi sp. nov., causative agent of current Dutch elm disease pandemics. Mycopathol 115: 151-161.

Brasier CM. 1996. Low genetic diversity of the Ophiostoma novo-ulmi population in North America. Mycol Res 88: 951-964.

Cannon PF, Kirk PM. 2007. Fungal Families of the World. CABI North American Office. 249-251.

Chen HY, Huang CG. 1999. Ulmaceace In: Flora Republicae Popularis Sinicae. Volume 22. Science Pres, Beijing, China. 328-386.

D'Arcy CJ. 2000. Dutch elm disease. The plant health instructor.

De Hoog GS. 1974. The genera Blastobotrys, Sporothrix, Calcarisporium and Calcarisporiella gen. nov. Stud Mycol 7: 1-84.

Dunn CP. 2000. The Elms: Breeding, Conservation, and Disease Management. Kluwer Academic Publishers, Norwell, MA.

Eriksson D, Baral H, Currah R, Hansen K, Kurtzman C, Rambold G, Laessoe T. 2003. Outline of Ascomycota-2003. Myconet 9:1403-1418.

Hoegger PJ, Binz T, Heiniger U, 1996. Detection of genetic variation between Ophiostoma ulmi and the NAN and EAN races of $O$. novoulmi in Switzerland using RAPD markers. Eur For Pathol 26: 57-68.

Hunt J. 1965. Taxonomy of genus Ceratocystis. Lloydia, 19:1-58.

Jacobi WR, Koski RD, Harrington TC, Witcosky JJ. 2007. Association of Ophiostoma novo-ulmi with Scolytus schevyrewi (Scolytidae) in Colorado. Plant Dis 91:245-247.

Jin XL, Zhang RQ, Zhang DL, He P, Cao FX. 2009. In Vitro plant regeneration of Zelkova carpinifolia, an endangered woody species in China, from leaf explants. J Hort Sci Biotech 84 (4): 415-420.

Masuya H, Brasier C, Ichihara Y, Kubono T, Kanzaki N. 2009. The genera Blastobotrys, Sporothrix, Calcarisporium and Calcarisporiella gen. nov. Stud Mycol 7. New Dis Rep 20: 6

Paoletti M, Buck KW, Brasier CM. 2006. Selective acquisition of novel mating type and vegetative incompatibility genes via interspecies gene transfer in the globally invading eukaryote Ophiostoma novoulmi. Mol Ecol 15:249-262.

Parker KG, Readio PA, Tayler LJ, Collins DL. 1941. Transmission of the Dutch elm disease pathogen by Scolytus multistriatus and the development of infection. Phytopathol 31:657-663.

Rahnama K. 2004. Dutch elm disease, survival of elm (Ulmus) and Zelkova species by integrated pest management and the conservation of forest genetic resources. Univ. British Colombia, Forest Sciences, Vancouver, Canada.

Sinclair WA, Campana RJ. 1978. Dutch elm disease : perspectives after 60 years. Cornell University Agricultural Experiment Station, Ithaca, NY.

Solla A, Dacasa MC, Nasmith C, Hubbes M, Gil L. 2008. Analysis of Spanish populations of Ophiostoma ulmi and O. novo-ulmi using phenotypic characteristics and RAPD markers. Plant Pathol 57: 33-44.

Solla A, Nasmith C, Dacasa MC, Fuentes-Utrilla P, Hubbes M, Gil L. 2005. First report of Ophiostoma novo-ulmi ssp. novo-ulmi on elms in the Iberian Peninsula. New Disease Reports 12, 34.

Stipes RJ, Campana RJ. 1981. Compendium of Elm Disease. American Phytopathological Society, St. Paul, MN.

Webber JF, Gibbs JN. 1989. Insect dissemination of fungal plant pathogens of trees. In: Wilding N, Collins NM, Hammond PM, Webber JF (eds). Insect-Fungus Interactions. Academic Press, London. 